\title{
Article
}

\section{Dealing with older workers in Europe: a comparative survey of employers' attitudes and actions}

\author{
Hendrik P. Van Dalen, Netherlands Interdisciplinary Demographic Institute \\ (NIDI) and CentER, Tilburg University, The Netherlands \\ Kène Henkens*, NIDI, The Netherlands \\ Joop Schippers, University of Utrecht, The Netherlands
}

\begin{abstract}
Summary This article addresses employers' attitudes and actions regarding the position of older workers. A comparative survey among employers from four European countries - Greece, Spain, the Netherlands and the United Kingdom - is used to examine their expectations with respect to the ageing of the workforce, the productivity of older workers and their recruitment and retention behaviour regarding this cohort. The results show that in spite of the perceived challenges ahead (including the ageing workforce), employers take no substantial measures to retain and recruit older workers or improve their productivity. Only employers in the United Kingdom seem to recognize older workers as a valuable source of labour supply and act accordingly.
\end{abstract}

Key words ageing, older workers, retirement, social policy, stereotypes

\section{Introduction}

The ageing of the population, combined with the low labour force participation of older adults, is of key policy concern to countries with extensive welfare states. Extending the working life is an objective that we find on almost every policymaker's agenda. Indeed, workers themselves expect to retire at a higher age than the actual retirement age in Europe which is currently below 60 (Velladics et al., 2006). It is interesting to note that whereas various measures are frequently suggested, or even promoted by policymakers, there is limited insight into how employers actually view the challenge of dealing with an ageing workforce (European Commission, 2004; 2005).

Most decisions on how to deal with an ageing workforce will have to be taken within individual organizations, or will, at least, be implemented within these organizations. Proposals and targets for extending working life are unlikely to be met without the active support and commitment of employers. Vickerstaff et al. (2003) state that any significant change in retirement behaviour will come primarily from policy modifications undertaken by employers. Therefore, this article examines the role played by employers in retaining and recruiting older workers. Earlier research among employers, carried out in the United States and several European countries, shows that many employers tend to be biased towards older workers and there is often a lack of corporate focus on older employees; this is reflected in an absence of programmes to retain and retrain them (Barth, et al., 1993; Chiu et al., 2001; Guillemard et al., 1996; Henkens, 2005; Taylor and Walker, 1998). Particularly when economic prospects are weak, older workers find

\footnotetext{
*Author to whom correspondence should be sent: Kène Henkens, NIDI, PO Box 11650, NL-2502 AR The Hague, The Netherlands. [email: Henkens@nidi.nl] 
Van Dalen et al.

Table 1 Labour market participation rate population aged 55-64 and total unemployment rate (2000-06)

\begin{tabular}{|c|c|c|c|c|c|c|c|}
\hline & 2000 & 2001 & 2002 & 2003 & 2004 & 2005 & 2006 \\
\hline \multicolumn{8}{|c|}{ Labour market participation } \\
\hline Greece & 39.0 & 38.2 & 39.2 & 41.3 & 39.4 & 41.6 & 42.2 \\
\hline Spain & 37.0 & 39.2 & 39.6 & 40.7 & 41.3 & 43.1 & 44.1 \\
\hline Netherlands & 38.2 & 39.6 & 42.3 & 44.3 & 45.2 & 46.1 & 47.7 \\
\hline United Kingdom & 50.7 & 52.2 & 53.4 & 55.4 & 56.2 & 56.9 & 57.4 \\
\hline EU (27 countries) & 36.9 & 37.7 & 38.5 & 40.0 & 40.7 & 42.3 & 43.5 \\
\hline \multicolumn{8}{|l|}{ Unemployment rate } \\
\hline Greece & 11.2 & 10.7 & 10.3 & 9.7 & 10.5 & 9.8 & 8.9 \\
\hline Spain & 11.1 & 10.3 & 11.1 & 11.1 & 10.6 & 9.2 & 8.5 \\
\hline Netherlands & 2.8 & 2.2 & 2.8 & 3.7 & 4.6 & 4.7 & 3.9 \\
\hline United Kingdom & 5.3 & 5.0 & 5.1 & 4.9 & 4.7 & 4.8 & 5.3 \\
\hline EU ( 27 countries $)$ & 8.6 & 8.4 & 8.8 & 9.0 & 9.0 & 8.7 & 7.9 \\
\hline
\end{tabular}

Source: Eurostat.

themselves in a vulnerable position, since early retirement is often seen as a less painful way to downsize the workforce than large-scale lay-offs. Whereas a growing share of the workforce consists of older workers and increasing labour shortages are imminent, the necessity to call upon the labour force potential of older workers may increase substantially.

This article addresses employers' attitudes and stated actions regarding the ageing of the population and its main consequences for the labour market and human resource policies. The article will address two main questions:

- To what extent is there a sense of urgency among employers regarding the ageing of the population and its consequences for the labour market? What do employers see as the possible implications of an ageing workforce for their organizations and how do they respond to these challenges?

- To what extent do employers see older workers as a potential pool of labour when they are confronted with labour supply shortages?

Answering these research questions will allow us to judge to what extent attitudes, expectations and actions are in line with the goals of European governments to increase older workers' labour market participation. In March 2001, the European Council of Stockholm defined, for the first time, a quantitative and highly ambitious target for raising the average labour force participation of older adults to 50 percent by 2010 for workers aged between 55 and 64 (European Council, 2001). The research questions will be answered with the aid of data from comparative surveys carried out in four European countries, namely the United Kingdom, the Netherlands, Greece and Spain. These four countries cover a wide range of economic activities. From a service-oriented, postindustrial economy like the Netherlands to the still partly rural economy of Greece. Moreover, they also cover different types of welfare states. From modern and market-oriented welfare states like the United Kingdom and the Netherlands to the still more traditional and familyoriented welfare state in Greece. In these four countries, several initiatives have been taken to increase the labour force participation levels of older workers. The employment rate of older workers aged 55 to 64 has increased substantially in recent years (see Table 1), although it is still below 50 percent (with the exception of the UK).

To a considerable degree, national policy measures that have been implemented regarding older workers are affected by the state of the economy. Countries suffering from high unemployment rates, like Greece and Spain (see Table 1), are more likely to develop measures to combat unemployment among older workers or measures that allow redundant older workers to leave the labour market without a substantial fall in income. Countries with lower unemployment rates or even labour market shortages (in our study, the United Kingdom and the Netherlands) are more likely to develop measures that stress the importance of keeping older workers working and improving older workers' productivity. In the Netherlands, substantial reforms aimed at 
restricting early exit from the labour force have been implemented in recent years by the abolition of fiscal facilitation of early retirement (VUT) and prepension arrangements (Reday-Mulvey and Velladics, 2005). The UK aims to increase employability of the potential labour force and at the same time reduce the burden of public pensions. The latter goal has been achieved in some cases by compromising the quality of pensions for many older people (TaylorGooby, 1999).

Realization of goals set at the government level, however, strongly depends on decision making at the micro level or in some cases at the meso level, while national authorities have only limited instruments to direct this decision-making process.

\section{Theoretical background}

\section{Ageing, productivity and wages}

Standard economic theory predicts that the demand for labour depends crucially on the relative prices of labour and capital and the technology employed to produce goods and services (Hamermesh, 1993). For the sake of brevity we will not discuss the influence of changes in the price of capital. Static neo-classical theory predicts that the price of labour is in line with the labour productivity of the individual worker. This spot market view of the labour market is bound to give a false impression because the declining agewage profile, as predicted by human capital theory, rarely occurs (OECD, 2006). Thurow (1975) was one of the first to suggest that while labour income and productivity are related, they are not necessarily related at every single moment in a worker's career. He explained that employers have an understanding - an implicit contract - with their employees regarding the relationship between productivity and earnings during the course of their careers. This understanding, Thurow stated, is based on the seniority principle, such that during the first phase of workers' careers their earnings are lower than their productivity and during the second phase their earnings are higher than their productivity. He explained that the prospect of a gradual rise in their incomes acts as an incentive for employees to continue working for 'their' employer, where their investments yield the highest returns.

Lazear (1979) stressed that this implicit contract is bound to be unsustainable if employees work beyond the age at which the net present value of wages exceeds that of the productivity profile. Therefore, employers will either opt for mandatory retirement schedules or the use of private pension schemes which penalize continued employment beyond a certain age. The trouble with these types of implicit contracts is that the sustainability of the contract is negatively affected by the ageing of the population. Seniority wages imply a heavy wage burden for employers. Whereas firms in some countries in the past could thrive because of a relatively young population age structure enjoying 'a demographic dividend' (Bloom and Williamson, 1998), now firms will have to face an ageing population structure and bear the costs of a 'demographic hangover' if nothing changes and labour force ageing takes its course.

Additional factors make an ageing population an even more serious liability, especially for employers operating in an open economy. First of all, there are taxes, social security premiums and pension premiums which increase the price of labour. This is a relevant factor as an ageing population increases the fiscal burden due to age-related pension and health care costs. An ageing population thus increases the gap between net and gross wages, making it either increasingly difficult to survive as a firm vis-à-vis firms in other countries that are not so hard hit by ageing populations. Thus it can become necessary for employers to shift the ageing burden towards employees, thereby decreasing the incentive to supply labour.

\section{Age, stereotypes and discrimination}

According to human capital theory, productivity depends on initial education and experience acquired over the life course. However, the older workers become, the more divergent experiences they accumulate. Labour supply is heterogeneous and employers can never be sure about the future productivity of an individual employee. This applies to employees currently enrolled, but even more so to new employees still to be hired. Employers are well aware of their employees' track records within their organization and they have information about employee productivity. However, employers do not know how workers' health may change as they age and whether they will be able to keep up with new technological developments. Employers have access 
Van Dalen et al.

to what Phelps (1972) called 'previous statistical experiences': information on how certain categories of employees tend to behave and develop. In particular when hiring, many employers use these statistical experiences to formulate expectations regarding the future productivity of employees who belong to a particular category (the uncertainty surrounding the productivity of the existing workforce is assumed to be less pronounced). In addition, research into the selection practices of employers who use candidate profiles - so-called 'vignettes' has shown that the selection criteria used tend to relate to characteristics of the applicants that cannot be changed, such as sex, age and social background (Van Beek et al., 1997). In an earlier study, Becker (1957) pointed out that employers may have 'a taste for discrimination' against some groups, and that this may - under certain circumstances - result in these groups not being employed by them at all.

It is well documented in the psychological literature that many stereotypes prevail among employers regarding the productivity of older workers. Stereotypes may partly be accurate representations of reality, or at least of the local reality to which the perceiver is exposed (Judd and Park, 1993). Stereotypes may, however, also lead to the social exclusion of older workers, not only because one may judge employees on the basis of average and inaccurate representations of the category, but also because stereotypes may lead to self-fulfilling prophecies when those who are subject to negative stereotypes behave accordingly (Hilton and Von Hippel, 1996). These stereotypes do not only relate to older workers' productivity, adaptability and loyalty, but also to the timing of retirement (Henkens, 2005). One of the more pervasive beliefs in today's workplace is that older workers should retire somewhere in their mid-50s or early 60s (Joulain and Mullet, 2001; McCann and Giles, 2003; Van Dalen and Henkens, 2005). At this particular point in life one should reap the rewards of years of hard work and enjoy one's 'golden years'. On the one hand, these views may be well intended and reflect positive attitudes towards older workers: a-well earned retirement at the end of a long career of hard work. On the other hand, as McCann and Giles (2003) indicate, the support of retirement may also reflect underlying attitudes that younger workers have more to offer to an organization than older workers. A belief among employers that older workers want to retire as soon as possible will hamper efforts to extend the working life.

\section{Data}

Based on the theory outlined above, a questionnaire entitled Fair Play for Older Workers was drawn up to provide insight into the attitudes and behaviours of employers. The questionnaires used in the different countries were identical. The four countries, however, have used a mixed strategy of approaching organizations (see Appendix). Questionnaires were posted and sent by email to organizations or delivered by hand. In Spain, face-to-face and telephone interviews were also carried out and respondents could choose to respond to the questionnaire online. Data collection took place from March to October 2005. The total number of completed questionnaires amounts to 1,855, of which 332 are from Spain, 597 from the Netherlands, 354 from Greece and 572 from the United Kingdom. Participating research institutes of the Fair Play programme carried out the data collection. ${ }^{1}$ Appendix A shows that data collection covered all sectors of the economy in each country. Comparison with Eurostat statistics (European Commission, 2006: 58) revealed that the data are representative for the sector distribution in each country, though employers in Greece and Spain often filled in 'other sectors' on the survey forms. For additional information regarding our sampling strategies we refer to Van Dalen et al. (2006).

\section{Results}

Ageing workforce: expectations, consequences and policies

We asked employers to what extent they expect problems in the labour market due to different societal developments. Employers perceive shortages of labour as one of the main labour market challenges for the coming decades. In Greece and the Netherlands, 62 percent of the employers anticipate problems due to a shrinking workforce. In Spain and the United Kingdom this percentage is somewhat higher at 64 and 72 percent respectively. The ageing of the population ranked high in Spain $(67 \%)$ and the Netherlands $(77 \%)$, but was ranked considerably lower in Greece (49\%) and the United Kingdom $(38 \%)$. The main conclusion based on these figures is that in all countries in our study there seems to be an awareness that demographic developments will affect the future labour force. It is worth noting that this awareness is significant also 
Table 2 Expected consequences ${ }^{a}$ of an ageing personnel structure for own organization (2005)

\begin{tabular}{lcccc}
\hline Consequences & Greece $\%$ & Spain $\%$ & Netherlands $\%$ & United Kingdom $\%$ \\
\hline Costs & & & & \\
$\quad$ Increase in labour costs & 62 & 52 & 77 & 42 \\
Greater resistance to change & 56 & 55 & 56 & 45 \\
Increase in absenteeism/sick leave & 69 & 54 & 53 & 40 \\
Less enthusiasm for new technology & 59 & 46 & 44 & 39 \\
$\quad$ Deterioration of the organization's image & 37 & 22 & 16 & \\
Benefits & & & & 78 \\
$\quad$ Increase in know-how and experience & 68 & 67 & 61 & 24 \\
Fewer conflicts within the organization & 34 & 37 & 73 & \\
Increase in productivity & 33 & 37 & & 43 \\
Organizational changes & & & 46 & 25 \\
$\quad$ More need to review how work is organized & 59 & 50 & 46 & \\
More need to improve working conditions & 51 & 49 & &
\end{tabular}

Note:

${ }^{a}$ Based on the question: 'If the average age of the employees in your organization increases, how likely or unlikely is it that the following outcomes will occur in your organization?'

Source: Fair Play employer survey (2005).

in the countries that still had a relatively high unemployment rate in 2005 such as Greece $(9.8 \%)$ and Spain $(9.2 \%)$ compared with 'low-unemployment' countries such as the Netherlands $(4.7 \%)$ and the United Kingdom (4.8\%).

Whereas there may be a sense of urgency among employers regarding demographic challenges in the labour market, expectations, perceptions and policies regarding their own organization may be quite different. What do European employers actually expect and do in the face of an ageing workforce in their organization? The employers' survey offers some observations on how employers will deal with this question.

Table 2 shows the answers to the question of how employers view the consequences of their own workforce's ageing. Here, a divide among employers becomes visible: UK employers are far more positive on the economic consequences of an ageing personnel structure within their own organization, whereas the Greek, Spanish and Dutch employers see an increase in labour costs and a greater resistance to change as dominant consequences. As can be seen in Table 2, employers in the four countries differ with respect to the consequences they think most likely to occur in an ageing workforce. In the United Kingdom and Spain, the top consequence is an increase in know-how and experience. In Greece, it is an increase in absenteeism, followed immediately by an increase in know-how and experience. In the Netherlands, employers predominantly expect an increase in labour costs. About half of all employers (in all four countries) expect increasing resistance to change. Similar shares of employers expect less enthusiasm for new technology, except for UK employers who seem somewhat more confident about the enthusiasm of older workers for new technology.

Evidently it is not all doom and gloom when it comes to evaluating the consequences of ageing and most employers acknowledge the increase in knowhow and experience which firms will enjoy when their personnel ages. However, the increase in knowhow apparently does not translate directly into higher productivity as most employers do not associate an ageing personnel structure with a higher productivity level. The discrepancy between know-how and productivity is largest for the Dutch employers: only 7 percent of them expect an increase in productivity. From a cost-benefit perspective this finding is probably the most worrisome: potential increases in productivity do not outpace increases in labour costs. Looking from this perspective - and if employers are right - it can be easily understood why many organizations see mainly drawbacks in retaining or recruiting older workers.

Employers may not only assess older workers separately but they may well do so in comparison with other human resources. The comparative advantages 
Table 3 Assessment by employers of functioning of older workers (50 years and older $)^{\mathrm{a}}$

\begin{tabular}{lcccc}
\hline Applicable or strongly applicable & Greece & Spain & Netherlands & United Kingdom \\
\hline Social skills & 79 & 82 & 76 & 89 \\
Reliability & 83 & 83 & 88 & 96 \\
Commitment to the organization & 83 & 80 & 83 & 92 \\
Accuracy & 71 & 73 & 77 & 88 \\
Customer-oriented skills & 69 & 76 & 73 & 87 \\
Mental capacity & 75 & 73 & 40 & 79 \\
Productivity & 53 & 69 & 40 & 82 \\
Creativity & 40 & 45 & 25 & 61 \\
Flexibility & 45 & 48 & 24 & 70 \\
Willingness to be trained & 42 & 30 & 9 & 54 \\
Physical capacity & 35 & 32 & 9 & 55 \\
New technology skills & 23 & 27 & 8 & 38 \\
\hline
\end{tabular}

Notes:

a Based on the question: 'To what extent are the following characteristics applicable to employees aged 50 years and older?' (Answer categories 1 'not applicable', 2 'little applicable', 3 'applicable', 4 'strongly applicable'.)

Source: Fair Play employer survey (2005).

Table 4 Differences in the assessments by employers of functioning of older ( 50 years and older) and young (35 years or younger) workers ${ }^{\mathrm{a}}$

\begin{tabular}{lcccc}
\hline Applicable or strongly applicable & Greece & Spain & Netherlands & United Kingdom \\
\hline Social skills & 11 & 29 & 50 & 34 \\
Reliability & 17 & 32 & 47 & 42 \\
Commitment to the organization & 25 & 43 & 44 & 48 \\
Accuracy & 7 & 11 & 43 & 23 \\
Customer-oriented skills & -6 & 15 & 26 & 25 \\
Mental capacity & -13 & -12 & -22 & -1 \\
Productivity & -33 & -9 & -37 & 9 \\
Creativity & -44 & -37 & -41 & -9 \\
Flexibility & -29 & -22 & -49 & 0 \\
Willingness to be trained & -48 & -58 & -77 & -36 \\
Physical capacity & -57 & -61 & -78 & -36 \\
New technology skills & -65 & -63 & -84 & -52 \\
\hline
\end{tabular}

Notes:

aBased on the questions: 'To what extent are the following characteristics applicable to employees aged 50 years and older?' The same question was asked with respect to employees younger than 35 years (Answer categories 1 'not applicable', 2 'little applicable', 3 'applicable', 4 'strongly applicable'.) Percentages in the table indicate the difference between the percentages applicable and strongly applicable for employees below age 35 and employees older than 50 years. Positive values indicate that older employees are better judged than younger employees. Negative values indicate that younger employees are better judged than older employees.

Source: Fair Play employer survey (2005).

are what matter from an economic point of view. That is why we asked the employers in our survey separate questions to evaluate characteristics of workers aged 50 and over and workers aged 35 and younger. Each employer was asked to assess to what extent (s)he found certain characteristics applicable for workers in a particular age bracket. We present the assessment of the functioning of older workers
(Table 3) and differences between the scores of the 'young' and the 'older' age category (Table 4) for each country.

Positive scores in Table 4 indicate that older workers are considered to perform better than younger workers. Negative scores in Table 4 indicate that younger workers are considered to perform better than older workers. The results for 
Table 5 Degree to which employers implemented measures or were considering implementing measures aimed at retaining older personnel $(\%)$

\begin{tabular}{|c|c|c|c|c|}
\hline Measures & Greece & Spain & Netherlands & United Kingdom \\
\hline \multicolumn{5}{|l|}{ Easing leisure/work trade-off } \\
\hline Part-time early retirement & 12 & 9 & 47 & 33 \\
\hline $\begin{array}{l}\text { Additional leave from work/extra days-off for } \\
\text { older workers }\end{array}$ & 7 & 4 & 57 & 10 \\
\hline Prolonged career interruptions & 7 & 8 & 10 & 12 \\
\hline \multicolumn{5}{|l|}{ Reducing stress at work } \\
\hline Age limits for irregular work & 7 & 4 & 31 & 3 \\
\hline Exemption from working overtime for older workers & 7 & 6 & 29 & 5 \\
\hline Flexible working hours & 12 & 16 & 21 & 32 \\
\hline Reducing workload for older workers & 18 & 11 & 33 & 15 \\
\hline \multicolumn{5}{|l|}{ Adjusting tasks/capabilities } \\
\hline Training programmes for older workers & 10 & 10 & 13 & 18 \\
\hline $\begin{array}{l}\text { Demoting older workers to a lower rank and } \\
\text { pay package }\end{array}$ & 6 & 3 & 6 & 16 \\
\hline \multicolumn{5}{|l|}{ Adjusting working conditions } \\
\hline Ergonomic measures & 8 & 13 & 50 & 14 \\
\hline
\end{tabular}

Source: Fair Play employer survey (2005).

each country paint, to a certain extent, a similar picture. Older workers are considered to be more reliable, more committed and have better social skills. Older workers are rated most negatively with respect to their willingness to be trained and the capacity to deal with new technologies. With regard to overall productivity the results are mixed. Employers from the United Kingdom assess older workers' productivity higher than that of young workers. The employers in the Netherlands have the most negative expectations with respect to productivity of the older worker.

The perceived comparative disadvantages of older workers can induce employers to take a number of steps. Table 5 lists the measures which employers have taken to retain and/or accommodate older personnel.

A first observation to be made is that Spanish and Greek employers have implemented just a few measures. Based solely on the number of actions taken, one would expect the older worker to be in the best position in the Netherlands. However, on closer inspection of the measures taken, it appears that the Dutch employer only typically implements politically correct measures, like extra leave, part-time retirement, and ergonomics, and avoids the harder measures (like demotion, which would raise conflict with employees and unions). Also the part-time retirement schemes are an example of costly measures that tend to 'spare' older workers. Fewer obligations and more privileges are generally proposed and negotiated. Privileges such as extra leave from work, age-related holiday entitlements, workload reduction, age limits for irregular work, or exemption from working overtime are quite normal in the Netherlands. Given all prior policy discussions both at the national and European levels - on issues like 'employability', lifelong learning and the need to turn Europe into a so-called knowledge-based society, it is remarkable that so few employers report offering training programmes for older workers. In Greece and Spain the number is only one out of ten; in the Netherlands it is one out of eight; and, in the United Kingdom, which shows the best performance in this field, it is still no more than one out of five to six employers.

\section{Older workers as a remedy for labour shortages}

Questions about whether there are, and will be enough workers to fill all jobs are of serious concern to the European employers in our study. Older workers may constitute an important and rich source of additional labour supply, but employers may prefer other measures to deal with shortages. 


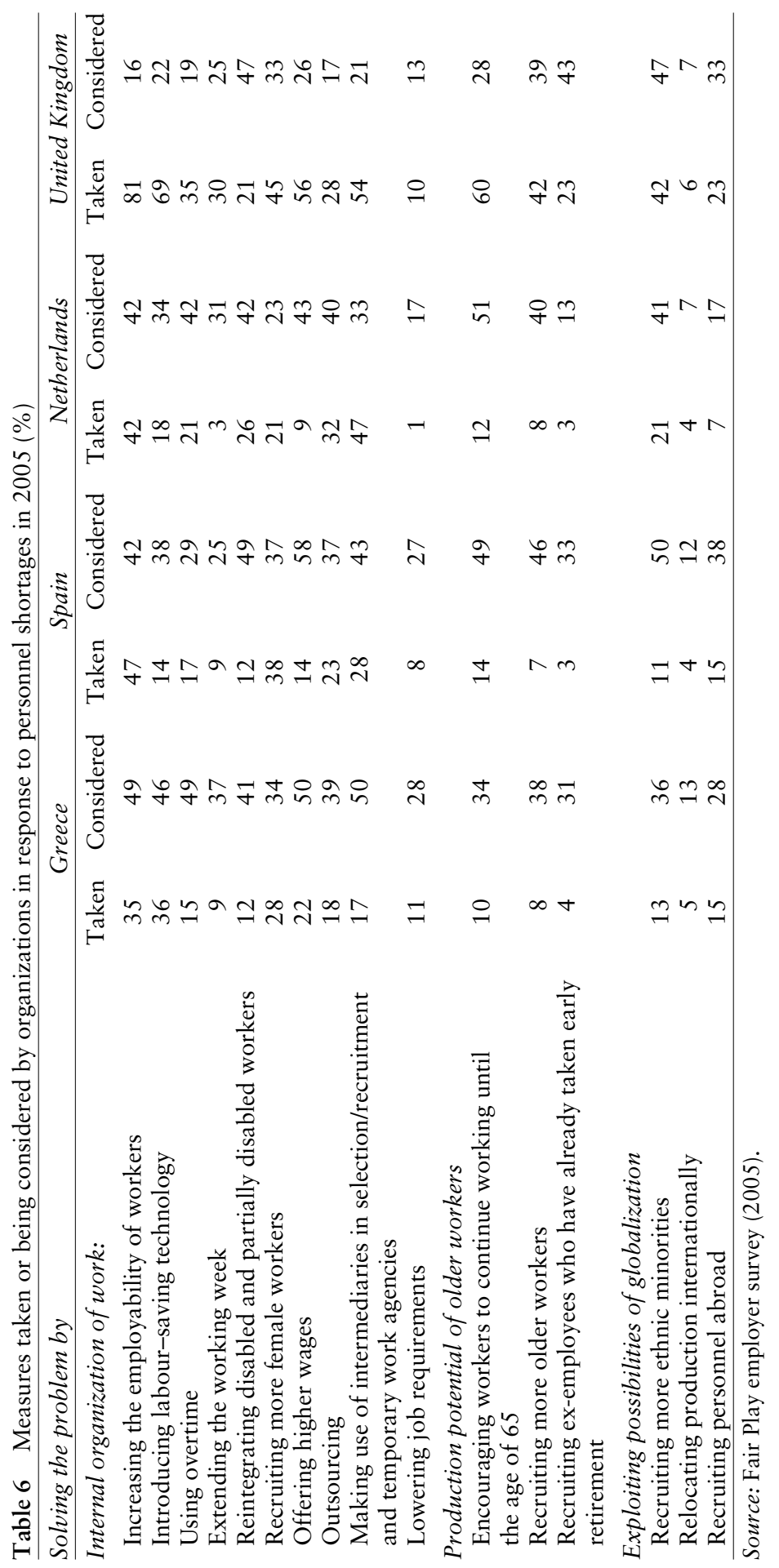


We asked employers what they have done and what they are considering doing to counteract personnel shortages (see Table 6).

Starting with actions already taken by employers, the results show that retaining or attracting older workers is generally not their first choice. This is in marked contrast with the rhetoric of Dutch policymakers who want to promote the position of older employees. Compared to Greece and Spain where very little has been done to retain the older worker, the behaviour of the Dutch employers regarding older workers is almost identical. The UK employers are far more set on using the capabilities of older workers as 42 percent stated they would recruit additional older workers and 60 percent would encourage workers to continue working to the statutory retirement age of 65 . In the United Kingdom, female workers, older workers and workers from ethnic minorities are equally popular among employers. Only disabled and partially disabled workers do not rank highly on the list of potential solutions for labour market shortages. The picture in the Netherlands is quite different. Here, disabled and partially disabled workers are an attractive group to supply additional labour. Women and immigrant workers share the second place, while older workers seem to be an option only for desperate employers. The actions and considerations in Greece and Spain show a similar picture: women are still considered to be the main source of additional labour supply. Disabled, partially disabled and immigrant workers share the second place. Here too, older workers are at the very end of the queue.

In Tables 7 and 8 we present multivariate logistic regression analyses carried out to analyse employers' behaviours towards older workers in more detail. We tested whether the country differences between employers' actions to recruit older workers and to retain older workers could be linked to structural differences among firms in the four countries.

In Model 1 we included only country dummy variables. In Model 2 we included occupational sector and characteristics of the firms' labour force as well as country dummy variables as independent variables. The results show that country differences cannot be traced back to differences in business type. Country differences, and also the magnitude of these differences, remain the same after the incorporation of other covariates in the models. Interestingly, the results show that employers who already have a

Table 7 Who is recruiting older workers? (logistic regression analysis)

\begin{tabular}{|c|c|c|c|c|}
\hline & \multicolumn{2}{|c|}{ Model 1} & \multicolumn{2}{|c|}{ Model 2} \\
\hline & Odds Ratio & t-value & Odds Ratio & t-value \\
\hline \multicolumn{5}{|l|}{$\begin{array}{l}\text { Sector of industry (manufacturing/ } \\
\text { construction = reference category) }\end{array}$} \\
\hline Service sector & - & - & 1.25 & 1.19 \\
\hline Public sector & - & - & 0.81 & 0.82 \\
\hline Sector unknown & - & - & 1.49 & 1.02 \\
\hline Size of the organization / 1000 & - & - & 1.00 & 0.19 \\
\hline Percentage of part-time staff & - & - & 1.30 & 0.82 \\
\hline Percentage of female staff & - & - & 1.20 & 0.56 \\
\hline Percentage of highly educated workers & - & - & 1.00 & 0.49 \\
\hline Percentage of workers over 50 years & - & - & $2.78^{\mathrm{a}}$ & 2.20 \\
\hline Market forces $(0=$ weak; $4=$ strong $)$ & - & - & 1.17 & 1.52 \\
\hline \multicolumn{5}{|l|}{ United Kingdom (= reference category) } \\
\hline Netherlands & $0.14^{\mathrm{b}}$ & 11.0 & $0.15^{\mathrm{b}}$ & 9.54 \\
\hline Greece & $0.11^{\mathrm{b}}$ & 9.7 & $0.12^{\mathrm{b}}$ & 7.78 \\
\hline Spain & $0.10^{\mathrm{b}}$ & 9.0 & $0.10^{\mathrm{b}}$ & 7.84 \\
\hline Pseudo $\mathrm{R}^{2}$ & \multicolumn{2}{|c|}{15.0} & \multicolumn{2}{|c|}{16.0} \\
\hline $\mathrm{N}=$ & \multicolumn{2}{|c|}{1855} & \multicolumn{2}{|c|}{1855} \\
\hline
\end{tabular}

Notes:

${ }^{\mathrm{a}}$ significant at $\mathrm{p}<0.05 ;{ }^{\mathrm{b}}$ significant at $\mathrm{p}<0.01$.

Dependent variable: Do you recruit older workers? $(1=$ yes, $0=$ no $)$ 
Van Dalen et al.

Table 8 Who is retaining older workers? (logistic regression analysis)

\begin{tabular}{|c|c|c|c|c|}
\hline & \multicolumn{2}{|c|}{ Model 1} & \multicolumn{2}{|c|}{ Model 2} \\
\hline & Odds Ratio & t-value & Odds Ratio & t-value \\
\hline \multicolumn{5}{|l|}{$\begin{array}{l}\text { Sector of industry (manufacturing/ } \\
\text { construction = reference category) }\end{array}$} \\
\hline Service sector & - & - & 1.15 & 0.83 \\
\hline Public sector & - & - & $0.65^{\mathrm{a}}$ & 1.84 \\
\hline Sector unknown & - & - & 1.04 & 0.14 \\
\hline Size of the organization / 1000 & - & - & 1.00 & 0.19 \\
\hline Percentage of part-time staff & - & - & 1.14 & 0.44 \\
\hline Percentage of female staff & - & - & 1.40 & 1.14 \\
\hline Percentage of highly educated workers & - & - & 1.00 & 1.37 \\
\hline Percentage of workers over 50 years & - & - & $2.19^{\mathrm{a}}$ & 1.82 \\
\hline Market forces ( $0=$ weak; $4=$ strong) & - & - & 1.13 & 1.43 \\
\hline \multicolumn{5}{|l|}{ United Kingdom (= reference category) } \\
\hline Greece & $0.08^{\mathrm{b}}$ & 12.1 & $0.09^{\mathrm{b}}$ & 10.4 \\
\hline Spain & $0.11^{\mathrm{b}}$ & 11.4 & $0.11^{\mathrm{b}}$ & 9.82 \\
\hline Pseudo $\mathrm{R}^{2}$ & \multicolumn{2}{|c|}{18.6} & \multicolumn{2}{|c|}{19.7} \\
\hline $\mathrm{N}=$ & \multicolumn{2}{|c|}{1855} & \multicolumn{2}{|c|}{1855} \\
\hline
\end{tabular}

Notes:

${ }^{\mathrm{a}}$ significant at $\mathrm{p}<0.05$; $^{\mathrm{b}}$ significant at $\mathrm{p}<0.01$.

Dependent variable: Do you encourage workers to remain employed till the age of 65 ? $(1=$ yes; $0=$ no $)$

large proportion of older workers in their staff are more inclined to recruit and retain older workers than 'young' organizations. This suggests that negative stereotyping of older workers may become less pronounced in ageing organizations.

There is a remarkable difference with respect to the appreciation of external developments between the United Kingdom and the other three countries participating in the project. In the United Kingdom, employers are much more open-minded towards the inflow of foreign workers than employers in the other countries, in particular the Netherlands. This may be due to a more flexible labour market in the United Kingdom. It may also have to do with different experiences concerning the type of immigrants among the countries.

In three of the four countries, increasing the employability of workers is the most popular measure to combat personnel shortages. As we saw earlier, this in general does not need to imply higher investments in training programmes for older workers. Of course, older workers may participate in training programmes developed for the entire staff. From the international literature it is well known that participation in 'general' training programmes usually decreases with age, and that workers over 50 hardly participate in such programmes (Bassanini et al., 2005; Booth, 1991; Elias and Davies, 2004). In Greece and especially in the United Kingdom, introducing labour-saving technologies is a much preferred option, contrary to practices in Spain and the Netherlands. Intermediaries and temporary work agencies seem particularly popular in the United Kingdom and the Netherlands. These labour market organizations do not play a major role in the labour market of the Mediterranean countries. Hardly any organizations prefer international relocation of production as a remedy to combat staff shortages. This implies that most employers will be oriented towards the national, local or regional labour market in the future as well. A general conclusion to be derived from these considerations is that employers in the United Kingdom are the most active in tackling the problem of labour market shortages. Employers in Greece and Spain have not taken many measures yet. This fits with our earlier conclusion that at this moment they do not feel the pressure of labour market shortages due to ageing as much as their colleagues from the northwestern part of Europe.

Raising the retirement age is often suggested as a structural solution. Paradoxically, employers expect this to occur mainly in other organizations, not in their own. Of all organizations in the UK survey, 73 percent expect the average age at which workers 
Table 9 What will happen to the actual retirement age? At national level and the level of own organization ${ }^{\mathrm{a}}$

\begin{tabular}{|c|c|c|c|c|c|c|c|c|}
\hline \multirow[b]{2}{*}{ Retirement age will: } & \multicolumn{2}{|c|}{ Greece } & \multicolumn{2}{|c|}{ Spain } & \multicolumn{2}{|c|}{ Netherlands } & \multicolumn{2}{|c|}{$\begin{array}{l}\text { United } \\
\text { Kingdom }\end{array}$} \\
\hline & Nat. & Org. & Nat. & Org. & Nat. & Org. & Nat. & Org. \\
\hline Increase & 50 & 22 & 28 & 17 & 72 & 49 & 73 & 45 \\
\hline Remain the same & 38 & 71 & 55 & 74 & 23 & 45 & 20 & 52 \\
\hline Decrease & 13 & 7 & 17 & 9 & 5 & 7 & 7 & 2 \\
\hline
\end{tabular}

Note:

a The question reads as follows: 'Over the next ten years (in society = Nat., in your organization = Org.) do you anticipate that the average age at which employees fully retire will increase, remain the same, decrease?'

Source: Fair Play employer survey (2005).

Table 10 Who should have the main responsibility in financing life course arrangements? The view of employers ${ }^{\mathrm{a}}$

\begin{tabular}{|c|c|c|c|c|c|c|}
\hline & Pensions & $\begin{array}{l}\text { Education of } \\
\text { the young }\end{array}$ & Childcare & $\begin{array}{l}\text { Lifelong } \\
\text { learning }\end{array}$ & $\begin{array}{l}\text { Unemployment } \\
\text { insurance }\end{array}$ & $\begin{array}{c}\text { Early } \\
\text { retirement }\end{array}$ \\
\hline \multicolumn{7}{|l|}{ Greece } \\
\hline Employer & 14 & 3 & 6 & 35 & 5 & 10 \\
\hline Employee & 7 & 28 & 29 & 34 & 7 & 12 \\
\hline Government & 79 & 68 & 66 & 31 & 89 & 78 \\
\hline \multicolumn{7}{|l|}{ Spain } \\
\hline Employer & 3 & 7 & 15 & 64 & 2 & 55 \\
\hline Employee & 9 & 22 & 37 & 11 & 4 & 7 \\
\hline Government & 88 & 72 & 48 & 25 & 94 & 39 \\
\hline \multicolumn{7}{|l|}{ Netherlands } \\
\hline Employer & 27 & 4 & 9 & 47 & 5 & 29 \\
\hline Employee & 49 & 34 & 55 & 51 & 6 & 44 \\
\hline Government & 24 & 62 & 36 & 2 & 89 & 27 \\
\hline \multicolumn{7}{|l|}{ UK } \\
\hline Employer & 13 & 0 & 2 & 12 & 0 & 19 \\
\hline Employee & 44 & 15 & 69 & 43 & 9 & 71 \\
\hline Government & 44 & 85 & 29 & 46 & 91 & 10 \\
\hline
\end{tabular}

Note:

a The question reads as follows: 'In your opinion, who should have the main responsibility for financing each of the following services?'

Source: Fair Play employer survey (2005).

leave the labour market to increase during the next ten years (see Table 9). However, only 45 percent of the employers expect such an increase for their own organization. In the Netherlands a similar divergence exists: 72 percent expect the overall retirement age to increase, and only 50 percent of the employers expect an increase for their own organization. Half of all employers in Greece and only 28 percent of Spanish employers expect the average age at which people leave the workforce to increase during the next ten years. In Greece 22 percent expect the same for their own organization. In Spain the figure is no more than 17 percent.

In conclusion, even though employers, especially in the United Kingdom and the Netherlands and to a lesser extent in Spain and Greece, experience and/or expect labour market shortages, they do not turn to older workers as a solution. These conclusions hold for the present. It will remain an open question whether employers will break with old habits and adapt their view of older workers when the ageing labour market is no longer a future event but a reality. 
Finally, to get a better idea of what kind of initiatives we can expect from employers in the future and to understand the past and present inactivity in retaining older workers, we examined how employers view the responsibilities for various arrangements which shape and finance the life course, such as education, childcare, retirement and unemployment. The question put before employers was normative in tone and asked who should have the main responsibility for financing life course services: employers, the employee or the government. All employers seem to agree that government should take the lead in many aspects of social policy, in particular unemployment insurance, childcare and education of the young. According to Table 10, the only aspects of social policy which employers view as their responsibility have to do with lifelong learning (with the exception of the UK) and to a lesser extent with early retirement. Early retirement is primarily supported as an easy way of downsizing a firm.

The results give strong empirical evidence for the description by Farnsworth (2005: 68) of the position of the international business community on social policy. Social policy in the view of employers' organizations should remain 'a productive factor' and welfare systems should be radically transformed so that 'they fit better with more competitive trading environments' (Farnsworth, 2005: 76). As Table 10 demonstrates, there is little support for social protection that may translate into higher production costs which might potentially undermine competitiveness.

\section{Conclusion and discussion}

To what extent is there a sense of urgency among European employers regarding the ageing of the population and its consequences for the labour market? And how do employers deal with older workers who will become a more dominant group in the future labour market? With these basic questions we compared the attitudes and actions of employers in four markedly different European countries. In Greece and Spain the ageing of society and the workforce is far less of an issue than in the United Kingdom and the Netherlands. This picture emerges from the analysis of employers' views on the prospects of an ageing labour market. This may explain why in Greece and Spain employers' views on older workers are less outspoken and why only limited policy initiatives have been taken so far.
Moreover, at the time of the survey. Greece and Spain still had to deal with high unemployment rates. In the Netherlands and in the United Kingdom ageing and older workers are more of an issue. However, the employers' views on older workers in these two countries clearly diverge. Dutch employers do not consider older workers a valuable asset in resolving future labour market shortages and they show little faith in a future with an ageing workforce. Primarily, they expect a growing discrepancy between rising labour costs and declining or - at best - stable productivity. As a consequence, Dutch employers' measures with respect to older workers boil down to granting them an easy and relaxed way out of the labour market. To a large extent this can be considered a legacy from the past when government policy initiatives were very much focused on the outflow of older workers to make room for young workers. Those were times when high unemployment figures for young people were a high priority on the policy agenda. Moreover, many Dutch employers share the opinion - and they are no exception to the large majority of Dutch people - that many older workers have 'paid' their share and are entitled by now to a well-deserved period of rest and retirement (Henkens, 2000).

UK employers do not seem to be burdened by a legacy to help older workers leave the labour market as smoothly as possible; they seem more convinced that they will become more dependent on older workers in the near future. Their attitude can be characterized in one quotation: 'Older workers are a fact of life - and you had better get used to that!' This attitude results in UK employers taking more measures to retain older workers for their organization and for the labour market than employers in the other countries participating in our study.

In comparing employer expectations and policies in the four countries, one can conclude that a huge gap exists between what employers perceive as general challenges ahead and actual policies within their own organization. The results underscore a difference between rationality at the macro level - as stressed by European policymakers - where society has to prepare for the consequences of demographic changes, and rationality at the micro level of employers - as illustrated by the answers to the questions in our questionnaire - where little effort is made to structurally improve the position of older workers in the labour market. Unless policymakers 
succeed in bridging this gap between micro and macro rationality, good ideas about working longer will remain with hardly any practical follow-up.

European Union policies are built on the idea that the prospects of future older workers will depend on the capacity of governments and social partners to make a success of lifelong learning. Investments in human capital and employability of workers who are currently in their 40s or 50s may (at least partly) prevent future problems with older workers' productivity. In the United Kingdom, only a very small minority of employers hold themselves primarily responsible for the lifelong learning of their employees. However, in the other examined countries, employers do see a task for themselves when it comes to lifelong learning. This looks encouraging and may present a starting point for a successful common approach. Nevertheless, by far the majority of European employers and their organizations are not yet ready to accommodate the ageing workforce.

If we compare our results with earlier surveys among employers there seems to be a substantial stability and continuity in the attitudes and behaviours across time and place regarding an ageing workforce and lack of corporate focus on extending the working life of workers (Remery et al., 2003; Taylor and Walker, 1998). TaylorGooby (2002) states, however, that empirical studies may overestimate this stability just at a point when radical changes are at stake. Future behaviour and attitudes may differ as a result of a structural break in labour market conditions; conditions which are hard for employers to detect or which at the moment can still be kept hidden due to a number of short-term measures.

Another limitation of this study is that the respondents are mostly people in higher management positions. Often these respondents are not the only persons involved in personnel selection decisions. Recent research by Van Dalen and Henkens (2005) suggests that many employees hold even stronger stereotypical views regarding older workers than do senior managers. This would suggest that our results may even underestimate negative stereotyping within organizations.

Future research may also pay more attention to different categories of personnel. Do employers hold different views with respect to older workers when it concerns skilled workers or unskilled workers? And do they undertake different measures for these two categories? Given the limited scope of our study, we could only set some first steps towards more insight into employers' views and understanding their behaviour towards older workers, and thus offer clues for government policies that may help to bring employers' behaviour in line with the overarching goals of increasing older workers' labour market partcipation.

Note

1 The Fair Play for Older Workers project is cofinanced by the European Union through a special measure called Article 6 under the budget heading 'Innovative approaches to the management of change' (see [www.fairplay.bdf.es] for more information).

\section{References}

Barth, M. C., McNaught, W. and Rizzi, P. (1993) 'Corporations and the Ageing Workforce', in P. H. Mirvis (ed.) Building the Competitive Workforce: Investing in Human Capital for Corporate Success, pp. 156-200. New York: Wiley and Sons.

Bassanini, A., Booth, A., Brunello, G., De Paola, M. and Leuven, E. (2005) 'Workplace Training in Europe', IZA Discussion Paper (No. 1640), Bonn.

Becker, G. S. (1957) The Economics of Discrimination. Chicago, IL: University of Chicago Press.

Bloom, D. E. and Williamson, J. G. (1998) 'Demographic Transitions and Economic Miracles in Emerging East Asia', World Bank Economic Review 12: 419-55.

Booth, A. (1991) 'Job-related Formal Training: Who Receives It and What is It Worth?', Oxford Bulletin of Economics and Statistics 53 (3): 281-94.

Chiu, W. C. K., Chan, A. W., Snape, E. and Redman, T. (2001) 'Age Stereotypes and Discriminatory Attitudes towards Older Workers: an East-West Comparison', Human Relations 54: 629-61.

Elias, P. and Davies, R. (2004) 'Employer Provided Training Within the European Union: a Comparative Review', in C. Sofer (ed.) Human Capital Over the Life Cycle: A European Perspective. Cheltenham: Edward Elgar.

European Commission (2004) Increasing the Employment of Older Workers and Delaying the Exit from the Labour Market. COM (2004) 146 final, Brussels.

European Commission (2005) Confronting Demographic Change: a New Solidarity Between the Generations. Green Paper, COM (2005) 94 final, Brussels.

European Commission (2006) Employment in Europe 2006, Brussels.

European Council (2001) 'Presidency Conclusions', Stockholm 23 and 24 March. Brussels.

Farnsworth, K. (2005) 'Promoting Business-centred Welfare: International and European Business Perspectives on Social Policy', Journal of European Social Policy 15 (1): 65-80.

Guillemard, A., Taylor, P. and Walker, A. (1996) 'Managing an Ageing Workforce in Britain and France', Geneva Papers on Risk and Insurance - Issues and Practice 21: 478-501. 
Hamermesh, D. S. (1993) Labor Demand. Princeton, NJ: Princeton University Press.

Henkens, K. (2000) 'Supervisors' Attitudes about the Early Retirement of Subordinates', Journal of Applied Social Psychology 30 (4): 833-52.

Henkens, K. (2005) 'Stereotyping Older Workers and Retirement: the Managers' Point of View', Canadian Journal on Aging 24: 35-48.

Hilton, J. L. and Von Hippel, W. (1996) 'Stereotypes', Annual Review of Psychology 47: 237-71.

Joulain, M. and Mullet, E. (2001) 'Estimating the "Appropriate" Age for Retirement as a Function of Perceived Occupational Characteristics', Work \& Stress 15: 357-65.

Judd, C. M. and Park, B. (1993) 'Definition and Assessment of Accuracy in Social Stereotypes', Psychology Review 100: 109-28.

Lazear, E. P. (1979) 'Why is there Mandatory Retirement?', Journal of Political Economy 87: 1261-74.

McCann, R. and Giles, H. (2003) 'Ageism in the Workplace: a Communication Perspective', in T. D. Nelson (ed.) Ageism, Stereotyping and Prejudice Against Older Persons, pp. 163-99. Cambridge, MA: MIT Press.

OECD (2006) Live Longer, Work Longer. Paris: OECD.

Phelps, E. S. (1972) 'The Statistical Theory of Racism and Sexism', American Economic Review 62: 659-61.

Reday-Mulvey, G. and Velladics, K. (2005) 'Employment of Older Workers in the Netherlands: Recent Reforms', European Papers on the New Welfare 1: 110-16.

Remery, C., Henkens, K., Schippers, J. J. and Ekamper, P. (2003) 'Managing an Ageing Workforce and a Tight
Labor Market: Views Held by Dutch Employers', Population Research and Policy Review 22: 21-40.

Taylor, P. and Walker, A. (1998) 'Employers and Older Workers: Attitudes and Employment Practices', Ageing and Society 18: 641-58.

Taylor-Gooby P. (1999) 'Policy Change at a Time of Retrenchment: Recent Pension Reforms in France, Germany, Italy and the UK', Social Policy \& Administration 33: 1-19.

Taylor-Gooby P. (2002) 'The Silver Age of the Welfare State: Perspectives on Resilience', Journal of Social Policy 31: 597-621.

Thurow, L. C. (1975) Generating Inequality. New York: Basic Books.

Van Beek, K. W. H., Koopmans, C. C. and van Praag, B. M. S. (1997) 'Shopping at the Labor Market: a Real Tale of Fiction', European Economic Review 41: 295-317.

Van Dalen, H. P. and Henkens, K. (2005) 'The Double Standard in Attitudes toward Retirement - the Case of the Netherlands', Geneva Papers of Risk and Insurance - Issues and Practice 30: 693-710.

Van Dalen, H. P., Henkens, K., Hendrikse, W. and Schippers, J. (2006) 'Dealing with an Ageing Labour Force: What do European Employers Expect and Do?', NIDI-report 73. The Hague: NIDI.

Velladics, K., Henkens, K. and Van Dalen, H. P. (2006) 'Do Different Histories Produce Different Policy Preferences? - Opinions on Pension Reforms in Eastern and Western Europe', Ageing \& Society 26 (3): 475-95.

Vickerstaff, S., Cox, J. and Keen, L. (2003) 'Employers and the Management of Retirement', Social Policy \& Administration 37: 271-87.

Appendix A

\begin{tabular}{|c|c|c|c|c|c|}
\hline Country & $\begin{array}{l}\text { Way of data } \\
\text { collection }\end{array}$ & $N$ & Response rate & $\begin{array}{l}\text { Sector distribution } \\
\text { in the sample }\end{array}$ & $\begin{array}{l}\text { Sector distribution } \\
\text { according to European } \\
\text { Commission (2006) }\end{array}$ \\
\hline Greece & $\begin{array}{l}\text { Sent by email and } \\
\text { distributed by hand }\end{array}$ & 354 & Not available & $\begin{array}{l}\text { Industry and } \\
\text { construction }(17 \%) \\
\text { Service sector }(47 \%) \\
\text { Public sector }(14 \%) \\
\text { Sector unknown }(22 \%)\end{array}$ & $\begin{array}{l}\text { Industry and } \\
\text { construction }(26 \%) \\
\text { Service sector }(47 \%) \\
\text { Public sector }(27 \%)\end{array}$ \\
\hline Spain & $\begin{array}{l}\text { Online questionnaire } \\
\text { and face-to-face } \\
\text { and telephone } \\
\text { interviews }\end{array}$ & 332 & Not available & $\begin{array}{l}\text { Industry and } \\
\text { construction }(17 \%) \\
\text { Service sector }(46 \%) \\
\text { Public sector }(7 \%) \\
\text { Sector unknown }(31 \%)\end{array}$ & $\begin{array}{l}\text { Industry and } \\
\text { construction }(32 \%) \\
\text { Service sector }(43 \%) \\
\text { Public sector }(24 \%)\end{array}$ \\
\hline Netherlands & By postal mail & 597 & $15 \%$ & $\begin{array}{l}\text { Industry and } \\
\text { construction }(25 \%) \\
\text { Service sector }(40 \%) \\
\text { Public sector }(35 \%) \\
\text { Sector unknown }(0 \%)\end{array}$ & $\begin{array}{l}\text { Industry and } \\
\text { construction }(21 \%) \\
\text { Service sector }(43 \%) \\
\text { Public sector }(36 \%)\end{array}$ \\
\hline $\begin{array}{l}\text { United } \\
\text { Kingdom }\end{array}$ & By postal mail & 572 & $6 \%$ & $\begin{array}{l}\text { Industry and } \\
\text { construction }(27 \%) \\
\text { Service sector }(37 \%) \\
\text { Public sector }(36 \%) \\
\text { Sector unknown }(0 \%)\end{array}$ & $\begin{array}{l}\text { Industry and } \\
\text { construction }(22 \%) \\
\text { Service sector }(43 \%) \\
\text { Public sector }(35 \%)\end{array}$ \\
\hline
\end{tabular}

